\title{
Indoor Air Quality Testing in Low-Energy Wooden Houses: Measurement of Formaldehyde and VOC-s
}

\author{
Csilla Patkó ${ }^{1}$, István Patkó ${ }^{2}$, Zoltán Pásztory ${ }^{3}$ \\ ${ }^{1}$ University of West Hungary, Innovation Centre, Bajcsy Zs. út 4, 9400 Sopron, \\ Hungary, csilla.patko@gmail.com \\ 2 Óbuda University, Doberdo út 6, 1034 Budapest, Hungary, patko@uni-obuda.hu \\ ${ }^{3}$ University of West Hungary, Innovation Centre, Bajcsy Zs. út 4, 9400 Sopron, \\ Hungary, pasztory@fmk.nyme.hu
}

\begin{abstract}
The objective of our study is to determine the indoor air quality of a low-energy wooden house. During the field measurements we detected the presence of formaldehyde $\left(34 \mu \mathrm{g} / \mathrm{m}^{3}\right), B T X\left(35.51 \mu \mathrm{g} / \mathrm{m}^{3}\right)$, and some materials in the terpene family, limonene (64.7 $\left.\mu \mathrm{g} / \mathrm{m}^{3}\right)$, and alpha-pinene $\left(297 \mu \mathrm{g} / \mathrm{m}^{3}\right)$, in the indoor air. The concentration of the detected TVOC (Total Volatile Organic Compounds) was $2150 \mu \mathrm{g} / \mathrm{m}^{3}$, which does not significantly differ from European average values. The LCI (Lowest Concentration of Interest) analysis shows that none of the VOCs tested by us are a health risk to the occupants in the building. However, it can be established that the health risk of benzene (0.622) stands out from the tested substances. The health risks of other aliphatic hydrocarbons (0.176) and alphapinene (0.198) may be considered identical, but even these do not pose a risk to humans. In order to clarify the sources of the harmful substances further investigations are needed.
\end{abstract}

Keywords: indoor air quality; VOC; formaldehyde; BTX; terpene; wooden building

\section{Introduction}

\subsection{The Development of Indoor Air Quality Testing}

Indoor air quality testing has come to the fore gradually in the past 30 years. The compounds concentrated in the air and entering into reaction with each other have an effect on human health. Formaldehyde and BTX (benzene, toluene, xylene) were the first such volatile organic compounds (VOC) whose harmful, carcinogenic effects were already recognized earlier. A major part of these comes from indoor sources such as human activity and the evaporation of the building 
materials of buildings. Several tests have been performed worldwide and there is significant professional literature available about the case studies conducted. As a result several guides and design aids have been created about the effects of harmful substances and their possible sources. Wood, as the ecological building material of the future, is gaining a new role in the design and realization of energy efficient houses.

Clean air is one of the most fundamental conditions of our life. In buildings where people spend most of their days indoor air quality greatly affects their comfort level and state of health [1]. People dealt with unpleasant odours and their effects on health already in the $18^{\text {th }}$ Century. In 1858 a German hygienist, Max von Pettenkoffer defined the maximum value of $\mathrm{CO}_{2}$ in indoor air $(0.1 \mathrm{vol} \%)$, which value still has not lost its relevance [2]. In the past 30 years more and more significant studies have been published on this subject. Before 1991 the main subject of indoor air testing was the protection against corrosion of indoor objects and the methods of preserving the condition of these objects.

James N. Pitts, Jr. was the first to identify and measure $\mathrm{NO}_{2}$ concentration in indoor air. In his book Chemistry of the Upper and Lower Atmosphere published in 2000 he already devoted one chapter to indoor air quality testing, which demonstrated the importance of the topic [3].

Another important compound is $\mathrm{CO}$, which is considered toxic to humans in higher concentration. Carbon monoxide is a temporary atmospheric pollutant in some urban areas, chiefly from the exhaust of internal combustion engines (including vehicles, portable and back-up generators, power washers, etc.), but also from incomplete combustion of various other fuels (including wood, coal, charcoal, oil, paraffin, propane, natural gas, and trash). Considering the fact, that new houses are more airtight and the ventillation rates are less, in closed environments the concentration of carbon monoxide can easily rise to lethal levels [28].

In America the testing of indoor harmful substances became the centre of attention in the early 1980s. These tests dealt with the detection and measurement of formaldehyde, radon, asbestos and volatile organic compounds (VOC). Through the development of laboratory technology with the help of more sensitive measurement tools more and more compounds can be detected and defined [4].

Between 1991 and 2000 only about 60 articles appeared on the subject of Indoor Chemistry. However, between 2001 and 2010 nearly 210 articles were published. Nevertheless, the testing of chemical substances in indoor air is still less developed compared to ambient air testing on which approximately 12,000 articles have been published in the past 20 years [5]. 


\subsection{The Purpose of Our Study}

In recent years a large number of houses with low energy consumption, so-called energy efficient houses have been built in Hungary. They do not only seek ecological solutions from building energetic points of view, but the choice of ecological materials has also come to the forefront. It is important that the building should not appear in the environment as a foreign body, but it should fit into natural cycles as much as possible.

Our research was the first in Hungary to perform air quality measurements in a newly built wooden structure house which had been constructed as a result of environmentally conscious design and building. This building contains wooden building blocks which are untreated or treated with natural materials. Our study focused on detecting the chemical substances - in the indoor air of the building which basically affect the indoor air quality.

\section{The Theoretical Background of Our Testing}

Some countries already have specific emission rates of different materials [6]. In 1992 Seifert classified the volatile organic compounds from building materials into three categories: on the basis of their long term effect on health (such as carcinogenic, mutagenic, teratogenic, allergenic, etc.), short term effects (such as mucous membrane irritation, etc.) and their unpleasant odour. However, this system did not yet take account of the possible emission degradation of the substances present in the atmosphere and its consequences [7, 8].

The guidelines of WHO (World Health Organisation) categorize the harmful substances emitted by the sources [9]. In Germany the Committee for the Health Assessment of Building Materials (AgBB - Ausschuss zur gesundheitlichen Bewertung von Bauprodukten) first defined VOCs from the emission of building products in 2000. Now more than 180 different VOCs can be defined [10].

Several other studies also deal with similar topics such as EnVIE, BUMA, HealthyAir [6]. The objective of this research is to provide architects with available information already in the design phase of buildings about such building materials (masonry blocks, tiles, etc.) that do not emit any harmful substances into the indoor air-space of the building. In the case of new buildings air quality may be best influenced by controlling the sources. 


\subsection{VOC Sources and Their Impact on Health}

VOC is a group of organic substances with boiling points between 50 and $260^{\circ} \mathrm{C}$, the best known of which are BTEXS (benzene, toluene, ethyl benzene, xylene and styrene) substances, terpenes ( $\alpha$-pinene, limonene), as well as formaldehyde and acetaldehyde among carbonyl compounds [11]. These are the main pollutants of indoor air with formaldehyde, benzene and acetaldehyde considered carcinogenic [12]. They may be found in almost all air-spaces because most household products contain them, such as paints, varnishes, waxes, conservation materials, solvents of anti-mould agents, detergents and cleaning agents. In the case of new buildings the main source of these substances is the primary emission from the building materials, which may last for several months. After the primary emission certain building materials emit further harmful materials into the air as these materials get older and used. This process is called secondary emission [13].

\subsection{Benzene}

Benzene is an industrial solvent which is widely used in paints, lacquers and for varnishing [14]. Today it is used as a raw material for producing plastics, resins and detergents. Benzene is present everywhere, for instance also in tobacco smoke. The results of measurements performed in buildings in different European cities have shown that it is not present in new houses in Finland. On the other hand, the highest measured concentration was $109 \mu \mathrm{g} / \mathrm{m}^{3}$ according to research [15]. In the latest study published by WHO benzene's carcinogenic effects are still emphasized and so is the possibility of developing acute myeloid leukaemia.

Since there is no exposure limit defined for benzene the risk factor for developing leukaemia at $1 \mu \mathrm{g} / \mathrm{m}^{3}$ concentration is $6 \times 10^{-6}$ during one lifecycle [1].

\subsection{Formaldehyde, Acetaldehyde}

Their main sources are the adhesives that are used for the production of chipboards, various resins, paints, disinfectants and paper products. They are found in cigarette smoke $[16,17]$. They may come from secondary emissions [11]. Possible sources are the stubble pages of furniture. The resin parts of stubble pages are made with the polymerization of formaldehyde monomers. The minimum amount which can cause eye irritation is $0.36 \mathrm{mg} / \mathrm{m}^{3} ; 0.6 \mathrm{mg} / \mathrm{m}^{3}$ will lead to mild conjunctivitis. A concentration of $0.1 \mathrm{mg} / \mathrm{m}^{3}$ is the quantity where neither the elderly nor children will suffer any irritation if the duration of exposure is less than 30 minutes. The concentration of formaldehyde indoors can be significantly influenced by the number of air exchanges. [1] 


\subsection{Terpenes (Limonene and $\alpha$-pinene)}

Limonene is an organic compound classified as a terpene, i.e. it is not synthetic but a real plant extract. It is a colourless liquid at room temperature with a strong smell of oranges. Lemons and other citrus fruit contain limonene in high quantities. It is used as a flavour and fragrance additive in food, household detergents and perfumes [18]. It can cause allergic symptoms such as eye, nose, throat and skin irritation, but generally it is not considered as a harmful substance. The average concentration measured in households is less than $30 \mu \mathrm{g} / \mathrm{m}^{3}$. This value is largely affected by whether any air fresheners or cleaning agents were used which may contain it in higher concentration [11].

$\alpha$-pinene is also a natural terpene, which might be emitted by surface-treated wood products, aerosols, paints and water-resistant solvents. It is not a carcinogen, just like limonene, it can only cause irritation. According to literature [19] on average less than $30 \mu \mathrm{g} / \mathrm{m}^{3}$ is present in indoor air. It is characteristic of both substances that they become easily oxidized due to ozone or other substances containing active oxygen [20].

\section{Overview of Case Studies from Professional Literature}

In Hungary several eco-epidemiological studies have been made by the National Institute of Environmental Health during the last 15 years. In 1998 several homes were selected in six Hungarian cities, where they measured the indoor air for formaldehyde, $\mathrm{NO}_{2}$, benzene, xylene and toluene concentrations. The research was intended to find the source of the substances measured indoors and to find correlations between the state of health of the children living in these homes and indoor air pollution. The tests showed that the $\mathrm{NO}_{2}$ present in the indoor air came from the kitchen gas cooker $\left(75 \mu \mathrm{g} / \mathrm{m}^{3}\right)$, gas convectors $\left(80 \mu \mathrm{g} / \mathrm{m}^{3}\right)$ and smoking $\left(27 \mu \mathrm{g} / \mathrm{m}^{3}\right)$. Benzene was detected in homes with under floor heating, while formaldehyde was detected in homes built from gas silicate masonry building materials. In addition to instrumental measurements, a questionnaire survey was also conducted among the residents. According to the result of the survey among the interviewed 1768 children $14.2 \%$ had symptoms of chronic bronchitis. Plastic floor covering increased allergy symptoms by $66 \%$ and congestion by $49 \%$. In prefabricated flats air-conditioners and fitted carpets exponentially increased the number of allergic symptoms. One conclusion of this study was to draw attention to the safe removal of the combustion products of domestic gas appliances, which does not only prevent health risks, but will greatly contribute to preventing mould growth in buildings [21]. 
In Paris a number of similar studies were also conducted using questionnaires and by taking multiple air samples in the homes. The Laboratoire Santé Publique et Environment Institute of the Universite Paris Descartes University conducted environmental surveys to find the indoor sources causing the allergic symptoms of newborn babies. Primarily they measured the aldehyde levels of indoor air for one year in the homes of 196 Parisian new-born babies. During their testing the concentration of formaldehyde of newly built buildings was $19.4 \mu \mathrm{g} / \mathrm{m}^{3}$. No correlation was found between heating, tobacco smoke and the concentration of formaldehyde. However, it was observed that the concentration of formaldehyde was higher in the summer. $8.9 \mu \mathrm{g} / \mathrm{m}^{3}$ of acetaldehyde was measured and it was established that indoor nicotine content, relative humidity and carbon dioxide levels affect acetaldehyde concentration. The conclusion was that the concentration of the aldehyde may be reduced by increasing ventilation [22].

In England the testing of the air-space of 876 newly-built homes showed that in the first year the concentration of formaldehyde in the indoor airspace was significant [23].

In Canada by examining 100 newly built homes Gilbert established in his study [24] that the concentration level of formaldehyde in the indoor air was influenced by the furniture or covering made of materials containing wood or melamine.

In South-Korea due to the large number of illnesses caused by the symptoms referred to as Sick Building Syndrome they placed a strong emphasis on indoor air quality in homes. Due to the use of low-quality building materials and insufficient ventilation - which was a consequence of mass constructions - and as a result of thermal insulation the concentration of VOCs significantly increased in the indoor air. The solution was to increase the ventilation of the rooms and use air cleaning agents [25].

\section{Formaldehyde and VOC Measurement Method}

\subsection{Description of the Tested Building}

The sampling was performed in a newly built, low energy wooden frame building. The construction was completed in the summer of 2012. It has an area of $120 \mathrm{~m}^{2}$, a ground-floor and an attic. Downstairs there are a hall, a living room with a kitchen, a room and a bathroom. From the living room there is a staircase leading up to the gallery, which opens into the room in the attic.

The structure of the building consists of wooden frames and wooden panels with Isocell insulation, which is rendered outside and covered with gypsum fibre panels inside. The interior walls are all solid wood panels without any chemical 
treatment. The house is heated with circulating hot air. The air is heated by solar collectors and geothermal heat. In addition, the ground-floor heating is supported by electric under-floor heating in winter. The sampling was performed in the room on the ground-floor, which is $12 \mathrm{~m}^{2}$ with a ceiling height of $2.8 \mathrm{~m}$. Two walls of the room are exterior side walls with windows of $84 \times 140 \mathrm{~cm}$, the other two walls are interior wood walls. The floor is covered with stone slabs. The room is unfurnished. The measuring instrument was placed in the middle of the room at a height of $1.2 \mathrm{~m}$.

\subsection{On-Site Measurements}

The sampling was performed in the building described in Section 4.1 and the samples were analysed by the laboratory of Wessling Hungary Ltd. Active sampling devices were used on the site. During the sampling the physical condition of the indoor airspace was the following: The indoor air temperature was $18^{\circ} \mathrm{C}$ continuously, the relative humidity was $41 \%$, the indoor, air exchange rate was $2.5 \mathrm{~m}^{3} / \mathrm{h}$, which means that during the measurement the windows and doors were closed [27]. In order to ensure the accuracy of laboratory measurements, the physical characteristics of indoor air had been set 24 hours before the sampling. Thus, the sampling was performed in a stationary state.

Two sampling tubes were connected to the active measuring device used for the sampling. One sampling tube was a $200 \mathrm{mg}$ Tenax TA stainless steel tube, $90 \mathrm{~mm}$ long, for sampling the VOCs.

Suction duration: $60 \mathrm{~min}$

Suction rate: $100 \mathrm{ml} / \mathrm{min}$

Suctioned air volume: $6000 \mathrm{ml}$

The other was a formaldehyde sampling tube filled with silica gel coated with 150/300 ml dinitrophenyl-hydrazine:

Suction duration: $240 \mathrm{~min}$

Suction rate: $200 \mathrm{ml} / \mathrm{min}$

Suctioned air volume: $48000 \mathrm{ml}$

\section{Evaluation of Measurement Results}

When we determined the VOC content of the samples taken from the indoor air we measured the concentrations of 180 components according to ISO standard $16000-6 / 2004$. The determination of formaldehyde was performed according to 
ISO 16000-3/2001. In Table 5.1 we included the measured concentrations of formaldehyde and of those VOC components out of the 180 measurement results whose values were significantly greater than the detection limit. Presumably, these are the substances which determine the quality of indoor air in the building.

The total VOC (TVOC) content was $2150 \mu \mathrm{g} / \mathrm{m}^{3}$. The total amount of the concentration of substances in Table 5.1 was $1508.06 \mu \mathrm{g} / \mathrm{m}^{3}$.

Table 5.1

Measured concentration of VOC components

\begin{tabular}{|c|c|}
\hline Component Name & Concentration $\left[\mu \mathrm{g} / \mathrm{m}^{3}\right]$ \\
\hline Benzene & 3.11 \\
\hline Toluene & 11.6 \\
\hline 1.3-Xylene and 1.4-Xylene & 20.8 \\
\hline n-Propylbenzene & 1.95 \\
\hline $\begin{array}{c}\text { Other aliphatic hydrocarbon } \\
(>C 8-C 16)\end{array}$ & 1060 \\
\hline Alpha-Pinene & 297 \\
\hline Limonene & 64.7 \\
\hline Hexanal & 48.9 \\
\hline Formaldehyde & 34 \\
\hline
\end{tabular}

\subsection{LCI (Lowest Concentration of Interest) Analysis}

German laws specify that VOC emission from building materials shall be reduced in the long term so much that it should not pose a risk to the health of the occupants in the building. The workgroup of AgBB (Ausschuss zur gesundheitlichen Bewertung von Bauprodukten) created a list of VOCs determining indoor air quality and at the same time gave the concentration limit of VOCs impairing air quality [26, 10]. If the concentration of the tested VOC is below the specified limit, it does not pose a health risk to the occupants in the building.

The degree of health risk is expressed by a ratio; the value of the measured concentration is divided by the limits according to $\mathrm{AgBB}$. If this ratio is $<1$, the tested substance does not pose a health risk. If the ratio is $>1$, the health risk caused by the substance is proportional to the value of the ratio. Table 5.2 contains the VOCs which we measured, their registration number (CAS), the limit of the concentration (LCI), the measured concentration and their quotient. We were not able to calculate the degree of health risk of formaldehyde. In the last prospective LCI value changes (June 2012) the LCI value for Formaldehyde was under discussion. 
Table 5.2

Health risk of measured substances

\begin{tabular}{|l|c|c|c|c|}
\hline Name of component & CAS & $\begin{array}{c}\text { LCI } \\
{\left[\mu \mathrm{g} / \mathrm{m}^{3}\right]}\end{array}$ & $\begin{array}{c}\text { Measured } \\
\text { concentration } \\
{[\mu \mathrm{g} / \mathrm{m} 3]}\end{array}$ & $\begin{array}{c}\text { Measured } \\
\text { concentration / } \\
\text { LCI }\end{array}$ \\
\hline Benzene (VOC) & $71-43-2$ & 5 & 3.11 & 0.622 \\
\hline Toluene (VOC) & $108-88-3$ & 1900 & 11.6 & 0.00061 \\
\hline $\begin{array}{l}\text { 1.3-Xylene and 1.4-Xylene } \\
\text { (VOC) }\end{array}$ & $\begin{array}{c}106-42-3 ; \\
108-38-3\end{array}$ & 2200 & 20.8 & 0.00094 \\
\hline n- Propylbenzene (VOC) & $103-65-1$ & 1000 & 1.95 & 0.00019 \\
\hline $\begin{array}{l}\text { Other aliphatic hydrocarbon } \\
\text { (>C8-C16) (VOC) (d) }\end{array}$ & & 6000 & 1060 & 0.176 \\
\hline Alpha-Pinene (VOC) & $80-56-8$ & 1500 & 297 & 0.198 \\
\hline Limonene (VOC) & $5898-27-5$ & 1500 & 64.7 & 0.043 \\
\hline Hexanal (VOC) & $66-25-1$ & 890 & 48.9 & 0.054 \\
\hline
\end{tabular}

Table 5.2 shows that none of the VOCs tested by us are a health risk to the occupants in the building. However, it can be established that the health risk of benzene (0.622) stands out from the tested substances. The health risks of other aliphatic hydrocarbons (0.176) and alpha-Pinene (0.198) may be considered identical, but even these do not pose a risk to humans.

\section{Conclusions}

Literature study no. [11] deals with the indoor air quality of buildings and publishes relevant data. It specifies the average value of pollutants measured in European cities. The comparison of our measured values and the values of article [11] are given in Table 6.1.

Table 6.1

Comparative values

\begin{tabular}{|c|c|c|c|}
\hline Name of component & $\begin{array}{c}\text { Concentration } \\
{[\mu \mathrm{g} / \mathrm{m} 3]}\end{array}$ & $\begin{array}{c}\text { European } \\
\text { average } \\
{[\mu \mathrm{g} / \mathrm{m} 3]}\end{array}$ & Evaluation \\
\hline Benzene (VOC) & 3.11 & 14.6 & passed \\
\hline Toluene (VOC) & 11.6 & $4-30$ & passed \\
\hline $\begin{array}{c}\text { 1.3-Xylene and 1.4-Xylene } \\
\text { (VOC) }\end{array}$ & 20.8 & $0-10$ & failed \\
\hline Limonene (VOC) & 64.7 & $0-30$ & failed \\
\hline Formaldehyde & 34 & $10-50$ & passed \\
\hline
\end{tabular}

It can be seen from Table 6.1 that the xylene and limonene content of the indoor air measured by us is higher than the average value measured in European cities. This fact does not yet mean that these substances pose a health risk. 
We tested indoor air quality in the interior space of a wooden residential building constructed in the area of the University of West Hungary (see Section 4.1). Before our study was designed and implemented we carried out detailed literature search on the subject. We explored the methods used in air quality testing. We compared the results obtained and we drew conclusions from them. Taking these into account we designed the on-site sampling and the laboratory measurements.

On the basis of the laboratory results we determined the health risks of the air to humans in the building tested. We compared the pollutant content of the indoor air space of our building with the measured values of European cities taken from the literature. It can be concluded that the quality of the airspace tested by us does not differ from the European average.

In this article we presented the measured values of VOC emissions. In order to clarify the sources of the harmful substances we are going to do further investigations.

\section{Acknowledgement}

This study was supported by the Environmental Analytical Laboratory of Wessling Hungary Ltd. and its employees.

This study was supported by the Environment conscious energy efficient building TAMOP-4.2.2.A-11/1/KONV-2012-0068 project sponsored by the EU and European Social Foundation.

\section{References}

[1] WHO: Guidelines for Indoor Air Quality: Selected Pollutants (2010) Denmark: WHO Regional Office for Europe, ISBN 9789289002134

[2] Wohnbauforschung, AGU: Hutter, H., Moshammer, H., Wallner, P., IMB: Tappler, P., Twrdik, F., ÖÖI: Dr. Ganglberger, E., Geissler, S., Wenisch, A. (2005) Auswirkungen energiesparender Maßnahmen im Wohnbau auf die Innenraumluftqualität und Gesundheit, Forschungsvorhaben F 1469, 15

[3] Barbara J. Finlayson-Pitts and James N. Pitts, Jr.: Chemistry of the Upper and Lower Atmosphere, Academic Press, 1999, p. 969

[4] Weschler, C. J. (2008) Changes in Indoor Pollutants since the 1950s, Atmospheric Environment 43 (2009) 153-169

[5] Weschler, C. J. (2011) Commemorating 20 Years of Indoor Air - Chemistry in Indoor Environments: 20 Years of Research, Indoor Air 2011; 21: 205218

[6] Bluyssen, M. P. (2009) Towards an Integrative Approach of Improving Indoor Air Quality, Building and Environment 44 (2009) 1980-1989

[7] Wolkoff, P., Nielsen, P. (1996) A New Approach for Indoor Climate Labeling of Building Materials--Emission Testing, Modeling, and Comfort 
Evaluation, Atmospheric Environment Vol. 30, No. 15, pp. 2679 2689, 1996

[8] Seifert B. (1992) Guidelines for Material and Product Evaluation. Ann. N.Y. Acad. Sci. 641, 125-136

[9] WHO. Air Quality Guidelines, Global Update 2005, Particulate Matter, Ozone, Nitrogen Dioxide and Sulphur Dioxide (2006) Denmark: WHO Regional Office for Europe, ISBN 9289021926

[10] AgBB (2012) Updated List of LCI values 2012 in Part 3, Health-related Evaluation Procedure for Volatile Organic Compounds Emissions (VOC and SVOC) from Building Products;

http://www.umweltbundesamt.de/produkte/bauprodukte/archive/agbb_eval uation_scheme_2012.pdf

[11] Sarigiannis, A. D., Karakitsios, P. S., Gotti, A., Liakos, I. L., Katsoyiannis, A. (2011) Exposure to Major Volatile Organic Compounds and Carbonyls in European Indoor Environments and associated Health; Environment International 37, 743-765

[12] Salthammer, T., Mentese, S., Marutzky, R. (2010) Formaldehyde in the Indoor environment. Chemical Reviews 110, 2536-2572

[13] Wolkoff, P., 1999. How to Measure and Evaluate Volatile Organic Compound Emissions from Building Products. A perspective. Science of the Total Environment 227, 197-213

[14] Holmberg B, Lundberg P. (1985) Benzene: Standards, Occurrence, and Exposure. Am J Ind Med; 7:375-83

[15] Zuraimi MS, Roulet CA, Tham KW, Sekhar SC, Cheong KWD, Wong NH, et al. (2006) A Comparative Study of VOCs in Singapore and European Office Buildings. Build Environ; 41:316-32

[16] Jurvelin J, Vartiainen M, Jantunen M, Pasanen P. (2001) Personal Exposure Levels and Microenvironmental Concentrations of Formaldehyde and Acetaldehyde in the Helsinki Metropolitan Area, Finland. J Air Waste Manag Assoc; 51:17-24

[17] EPA California. U. Accessed in November (2003) OEHHA Office of Environmental Health Hazard Assessment. http://www.oehha.ca.gov/air/chronic_rels/

[18] Kotzias D, Geiss O, Tirendi S. (2005) The AIRMEX (European Indoor Air Monitoring and Exposure Assessment) Project report. European Commission; http://web.jrc.ec.europa.eu/project/airmex/index.htm

[19] Rehwagen M, Schlink U, Herbarth O. (2003) Seasonal Cycle of VOCs in Apartments. Indoor Air; 13:283-91 
[20] Uhdea E, Salthammer T. (2007) Impact of Reaction Products from Building Materials and Furnishings on Indoor Air Quality - a Review of Recent Advances in Indoor Chemistry. Atmospheric Environment; 41:3111-28

[21] Rudnai P., Virágh Z., Vaskövi B.(1999): Egyes lakótéri tényezők szerepe iskolás gyermekek légzőszervi panaszainak és allergiás tüneteinek gyakoriságában. Egészségtudomány 43, 196-209

[22] Dassonville, C., Demattei, C., Laurent, A. -M., Le Moullec, Y., Seta, N., Momas, I. (2009) Assessment and Predictor Determination of Indoor Aldehyde Levels in Paris Newborn Babies_ Homes; Indoor Air 2009; 19: 314-323

[23] Raw, G. J., Coward, S. K., Brown, V. M. and Crump, D. R. (2004) Exposure to Air Pollutants in English Homes, J. Expo. Anal. Environ. Epidemiol., 14 (Suppl 1), S85-S94

[24] Gilbert, N. L., Gauvin, D., Guay, M., Heroux, M. E., Dupuis, G., Legris, M., Chan, C. C., Dietz, R. N. and Levesque, B. (2006) Housing Characteristics and Indoor Concentrations of Nitrogen Dioxide and Formaldehyde in Quebec City, Canada. Environ. Res., 102, 1-8

[25] Sun-Sook, K., Dong-Hwa, K., Dong-Hee, C., Myoung-Souk, Y., KwangWoo, K. (2006) Comparison of Strategies to Improve Indoor Air Quality at the Pre-Occupancy Stage in New Apartment Buildings; Building and Environment 43 (2008) 320-328

[26] ECA (1997) (European Collaborative Action "Indoor Air Quality and its Impact on Man"): Evaluation of VOC Emissions from Building Products Solid Flooring Materials. Report No. 18, EUR 17334 EN, European Commission, Joint Research Centre, Environment Institute

[27] Dr. Menyhárt Jószef: Az épületgépészet kézikönyve (1978) Müszaki könyvkiadó Budapest

[28] Green W. "An Introduction to Indoor Air Quality: Carbon Monoxide (CO)". United States Environmental Protection Agency. Retrieved 2008$12-16$ 